\title{
Empirical Analysis for Measuring Travel Time Reliability on Road Network
}

\author{
Karami, M.1*, Herianto, D. ${ }^{1}$, Ofrial, S.A. ${ }^{1}$, and Yulianti, N. ${ }^{1}$
}

\begin{abstract}
This research analyses the characteristics of travel time reliability for the road network in Kota Bandar Lampung, Lampung, Sumatera, Indonesia. Travel time consists of access, wait and interchange time, while its reliability deals with variations of in-passenger/private cars time. Survey of travel time on each road was carried out for 12 hours (from 06.00 to 18.00) for five working days. The buffer time method was used to measure the characteristics of time travel reliability which consisted of five measuring tools, namely planning time, planning time index, buffer time, buffer time index and travel time index. This research found that the temporal effects are the main factor that tends to affect travel time, whereas network effects are the second factor that tends to affect travel time. Furthermore, the regression equation was developed to express the effect of planning time (Tplan) and free-flow travel time on average travel time $(\bar{t})$.
\end{abstract}

Keywords: Buffer time methods; travel time; travel time reliability.

\section{Introduction}

Travel time reliability is used to determine the performance of a road network. It measures the expected duration of a trip within a specific time interval. It reflects the uncertainties and turbulence of daily traffic condition. Therefore, the average and variance of travel time on a particular road are essential to travelers because of its contribution to their choice of route.

Reliability signifies the constancy of travel time for any repeated trip. According to Tu [1], it is the probability of a road network to implement compulsory measures under environmental and operational conditions within a specified period. However, the statistical concept of variability is closely associated with reliability. Travel time variability occurs due to the different vehicle types with similar flow rates, and the reaction of drivers under certain conditions such as weather, and delays experienced at intersections, as well as numerous other incidents. It causes uncertainties, for instance, it complicates the decisions of travelers that are not aware of the precise arrival time for a planned public transport service regarding departure time, route, and even mode choice. This risk causes them to be willing to pay extra in order to achieve greater reliability as well as to avoid congestion during travel times.

${ }^{1}$ Civil Engineering Department, Universitas Lampung, Лl. Soemantri Brojonegoro No.1, Gedung Meneng, Bandar Lampung 35145, INDONESIA

*Corresponding author; Email: muhammad.karami@eng.unila.ac.id

Note: Discussion is expected before November, $1^{\text {st }} 2021$, and will be published in the "Civil Engineering Dimension", volume 24, number 1, March 2022.

Received 01 February 201; revised 19 March 2021; accepted 04 August 2021.
The performances of a transportation network in problematic areas are evaluated by certain measures, namely the duration of congestion and functional systems at the location. However, Higatani et al. [2] reported that travel time is extremely relevant to network users and planners. The term travel time reliability specifies the variations in travel times. This concept correlates with unpredictability [3]. According to Lyman and Bertini [4], it refers to the constancy of a given trip's travel time. Generally, it is defined as the consistency or dependability in travel times, which is measured from day to day or across different times of the day. Higatani et al. [2] stated that it is the probability of a journey from a specific origin to a particular destination within a given time interval. According to the Florida Department of Transportation, travel time reliability is an anticipated or additional acceptable time [5]. The United States Federal Highway Administration (FHWA) [6] stated that it is the constancy in travel time identified daily. Chang [3] reported that some factors result in unstable travel times, namely incidents, work zone, weather, fluctuations in demand, traffic control devices, and inadequate base capacity. These are linked to non-repetitive delays which focus on unexpected congestion caused by unpredictable events. In addition, Bremmer et al. [7] and Mahmassani et al. [8] reported that routine traffic volume usually caused a predictable recurrent delay, which targets the analysis of travel time savings in transport appraisal.

Bhouri et al. [9], Bates et al. [10] and Noland \& Polak [11] reported that the travel time variability is more significant than the mean travel speed in circumstances where a traveler plans a trip irrespective of the fact that the road is steadily congested, as well as uncertain conditions that enforce tremendous frustration. Shao et al. [12] stated that the mean travel 
time and reliability need to be considered when determining a specific route. According to Liu et al. [13] and Dong and Mahmassani [14], travel time reliability plays a significant role in the traveler's choice of route. Moreover, the performance of a road network is improved by providing anticipatory travel time information in the route guidance system and trip planner [15]. Accordingly, there is a need to include travel time reliability in the evaluation and appraisal of transport projects and programs [16]. As a component of transport systems, Li et al. [17] stated that it results in additional costs and uncertainty, and also tends to have an impact on a variety of travel choices such as time, route, and mode. Therefore, drivers often prepare a buffer time by leaving home early enough in order to ensure that they arrive on time. However, the travel time is difficult to predict when the level of traffic congestion changes daily, thereby resulting in a more serious problem.

Travel time reliability is an important measure of healthy transportation systems in any region. This is due to the following significant reasons (a) reducing delay as a result of traffic-influenced events (e.g. traffic incidents, bad weather, and work zones), and (b) reducing total congestion saves time, fuel, and vehicle emissions [18]. Furthermore, the transportation system has an enormous influence on the travelers and industry, and consequently, travel time reliability also helps in making it more efficient. According to Ando and Taniguchi [19], an efficient transportation system are required to boost competitiveness, reduce the level of traffic congestion and energy consumption in urban areas. Li et al. [17] and Taylor [20] stated that travel time reliability is important to travellers because it offers greater prominence in transport policy and performance management. Accordingly, it needs to be included in protecting forecasting and appraisal studies on the road network. In big cities, transportation planners have also used this analysis as a reference for organizing the system. Furthermore, the emphasis is laid on travel time reliability, specifically by commuters and industries that rely on precise travel times to deliver their goods. Chen et al. [21] stated that one advantage of an effective transportation system and the quality of road network services is measured by using travel time reliability.

In Kota Bandar Lampung, Lampung, Sumatera, Indonesia, the rapid increase of road users resulted in traffic congestion, which affects not only the mean travel time, it also decreased the travel time reliability. The continued growth of the economy and improved quality of life in this city contributed to the increased value of time, particularly for travelers. Therefore, increased duration of traffic congestion in the city intensifies harshness, and its duration has two effects, (1) increase in the average travel time and (2) travel times becomes irregular and unpredictable. Consequently, it has an ineffective significance on travel time reliability. However, it is expected that actions aimed at decreasing congestion also enhances the reliability of the transport network in the city.

Accordingly, information concerning travel time reliability is extremely important during policy implementation because it is a measure of the possible obtainable benefits. Travel time reliability is used to assess the performance of the transportation system as well as to attract investors to the city. The main objective of this research was to analyze the characteristics of travel time reliability for road networks in Kota Bandar Lampung. In addition, this resulted in a more effective transportation system in the city.

\section{Methods}

\section{Research Location}

The location where this study was carried out consists of Z.A. Pagar Alam (two-way traffic flow, from Tugu to Mall Bumi Kedaton (MBK), and from MBK to Tugu), Teuku Umar (two-way traffic flow, from MBK to Tanjung Karang and from Tanjung Karang to MBK), Radin Inten (one-way traffic flow), Ahmad Yani Road (one-way traffic flow) and R.A. Kartini Roads (one-way traffic flow) as shown in Figure 1. These are all major roads (primary arteries) in Kota Bandar Lampung, they are interconnected and accommodate large traffic flow. The characteristics of the road are shown in Table 1.

\section{Travel Time and Speed Survey}

This research was carried out based on two conditions, firstly, travel time reliability deals with a variety of in-passengers or private cars time, excluding commercial vehicles such as trucks, buses,

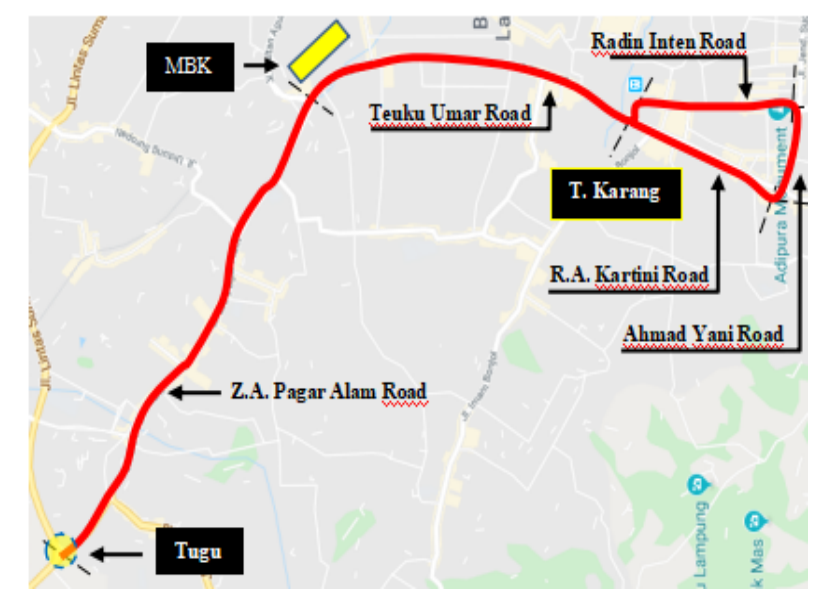

Figure 1. Road Segments 
Table 1. The Characteristics of Roads

\begin{tabular}{lllll}
\hline Road Name & Road Status & Length $(\mathrm{m})$ & Type & Width $(\mathrm{m})$ \\
\hline Z.A. Pagar Alam & National & 3.761 & Six lanes two-way divided & 18 \\
Teuku Umar & National & 2.985 & Six lanes two-way divided & 18 \\
Radin Inten & National & 1.434 & Three lanes one-way & 12 \\
Ahmad Yani & National & 0,609 & Three lanes one-way & 12 \\
R.A. Kartini & National & 1,434 & Four lanes one-way & 14 \\
\hline
\end{tabular}

trailers, and motorcycles. Travel times consist of access, wait, and interchange time. However, wait times are related to the unreliability of certain services, for example in some locations such as U-turn facilities, roadside activities (school or university areas, market, hospital etc.) reflects variations of invehicle times. This means that the unpredictability of in-vehicle journey times is the main target of this research. Secondly, the conceptuality of the reliability addresses operational failures, which are used to represent delays or unpredictable journey time. Therefore, the term reliability depicts uncertainties and variability of travel time for private cars. The travel time as well as the free flow travel time (FFTT), on each road was surveyed for 12 hours (from 06.00 $\mathrm{AM}$ to $06.00 \mathrm{PM}$ ) across different times of the day in any departure time and this lasted for five working days. Furthermore, speed fluctuations on the roads were directly obtained, using speedometer application program.

\section{The Characteristics of Travel Time Reliability}

The buffer time method was used to measure the characteristics of travel time reliability. This method offers additional time to ensure prompt arrival, and it simply means measuring travel time based on ant trip that is experiencing delays. In addition, this method, consist of five tools used to measure the reliability of travel time, namely planning time, planning time index, buffer time, buffer time index, and travel time index. They are further explained as follows [1-4]

a. Planning time $\left(T_{\text {plan }}\right)$ describes the given probability of the total travel time. Consequently, 95\% probability depicts the worst travel time that commuters tend to experience monthly, for instance, once out of 20 business days. The planning time is incomparable to different routes.

b. Planning time index $(P T I)$, is the ratio of the planning time $\left(T_{\text {plan }}\right)$ to the free-flow travel time (FFTT) as shown in Equation 1. This index indicates the severity of traffic congestion at any given the time of day in comparison with the free flow traffic condition.

$$
P T I=\frac{T_{p l a n}}{F F T T}
$$

c. Buffer time is defined as planning time minus average travel time $(\bar{t})$. It depicts the extra time which ascertains prompt arrival to the destination. However, this extra time accounts for any unexpected delay. Similarly, the buffer time is almost proportional to the variance of the travel time. It is also incomparable to different routes.

d. Buffer time index (BTI) is the ratio of buffer time to the average travel time. It was calculated by subtracting the $95^{\text {th }}$ percentile travel time from the mean travel time. The result was further divided by the average travel time (Equation 2).

$$
B T I=\frac{\left(T_{\text {plan }}-\bar{t}\right)}{\bar{t}}
$$

e. Travel time index (TTI) is the average time to travel during peak hours compared to free-flow conditions. TTI is equivalent to the mean travel time divided by the free-flow travel time (FFTT).

$$
T T I=\frac{\bar{t}}{F F T T}
$$

\section{Results and Discussion}

\section{Travel Time Variability}

It is a well- known fact that traffic congestion is heavy in some days of the week than others. Similarly, it is heavily experienced during certain hours of the day (e.g. morning or afternoon peaks) unlike late morning or afternoon off peaks. Travel time variability was classified into three categories namely (1) variability of inter-day generated by sessional and day-to-day variations (such as demand, accidents, road construction, and weather changes), (2) variability of interperiod which shows the effect of congestion on departure time, and (3) variability of inter-vehicle which is primarily as a result of individual driving styles and traffic signal. Furthermore, it determines the randomness in travel times over recurrent trips. This concept urges the individual to make decisions based on unpredictable conditions of the travel time. This is due to the inability to predict the exact travel time or arrival time before the trip is started. A strong relationship exists between travel time and congestion, for example, travelers encounter difficulties predicting the day-to-day travel time caused by road accident or the cancellation of certain services. However, travelers are able to anticipate the variation in travel time as a result of the congestion that occurs both at the peak and off-peak hours.

The travel time patterns on all roads networks in Kota Bandar Lampung are shown in Figure 2. The figure illustrates average values of travel time profiles as a function of departure time on working days. 

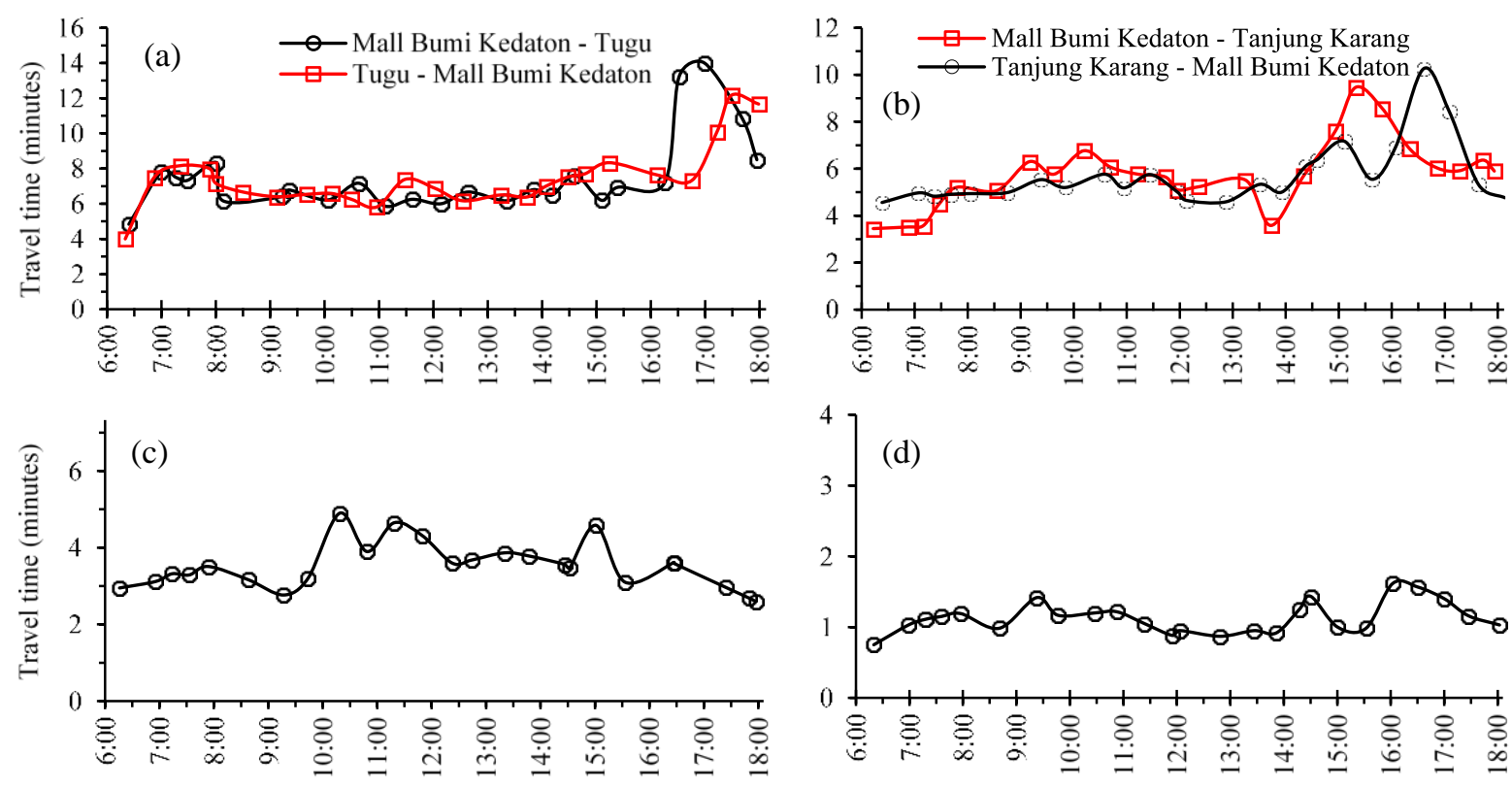

Departure time

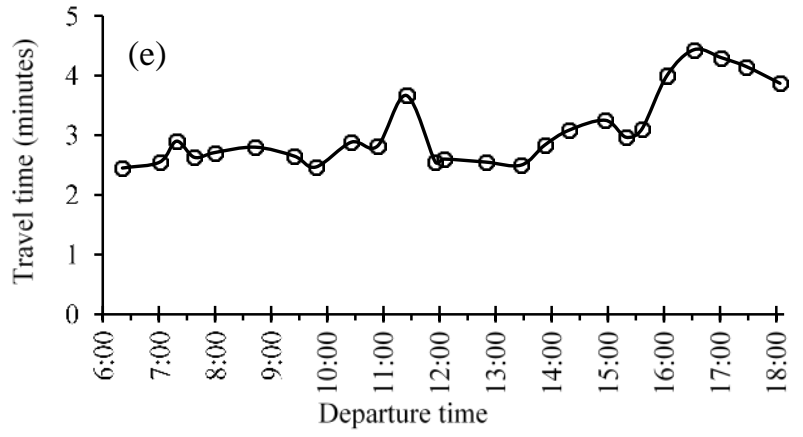

Figure 2. Average Values of Travel Time Data for Roads (a) Z.A. Pagar Alam, (b) Teuku Umar, (c) Radin Inten, (d) Ahmad Yani and (e) R.A. Kartini

The diagrams clearly show the trend of higher travel times during peak periods. There was a significant increase during the AM and PM peak, except the Radin Inten Road. The remaining four other roads showed that the travel times during AM (from 07.00 to 08.00 ) and PM (from 16.00 to 18.00 ) peak hours were longer than in midday (from 08.00 to 16.00). This is illustrated by the characteristics associated with the utilization of Radin Inten Road, which was mostly for the transportation of goods and business trips other than commuting, as shown in Figure 1c. Travellers encounter several uncertainties during the peak hours, thereby causing temporal effects and variance on the mean traffic flow. This implies that fluctuation of demand during the day causes road capacities to be inefficiently utilized.

Furthermore, network effects are the second factor that tends to affect travel time. They are the effect of traffic conditions on adjacent and connecting roads. Its influence on travel time is reported further in subsection Travel Speed Fluctuation. The maximum travel time was obtained at peak hours, particularly in the mornings and evenings, which is relatively 1.4 - 1.9 times its average. This shows that the dynamic traffic demand is determined by the multi-dimensional origin-destination matrixes, which are the departure rates from each origin to the destination nodes. A significant difference in travel times was measured based on the concentration of commuters during work hours. In terms of variance, the traffic flow patterns as a function of departure time differ substantially.

Table 2. Statistical Analysis of the Travel Time

\begin{tabular}{|c|c|c|c|c|}
\hline \multirow[t]{2}{*}{ Road Name } & \multirow{2}{*}{$\begin{array}{c}\text { FFTT } \\
\text { (minutes) }\end{array}$} & \multicolumn{3}{|c|}{$\begin{array}{c}\text { Travel Time } \\
\text { (minutes) }\end{array}$} \\
\hline & & $\overrightarrow{\text { Mear }}$ & SD & $\mathrm{CoV}(\%)$ \\
\hline \multicolumn{5}{|l|}{ Z.A. Pagar Alam: } \\
\hline - from MBK to Tugu & 4,05 & 7,49 & 2,17 & 29 \\
\hline - from Tugu to MBK & 3,90 & 7,43 & 1,74 & 23 \\
\hline \multicolumn{5}{|l|}{ Teuku Umar: } \\
\hline - from MBK to T.Karang & 3,45 & 5,74 & 1,46 & 25 \\
\hline - from T.Karang to MBK & 4,10 & 5,68 & 1,32 & 23 \\
\hline Radin Inten & 2,50 & 3,53 & 0,60 & 17 \\
\hline Ahmad Yani & 0,68 & 1,13 & 0,22 & 20 \\
\hline R.A. Kartini & 2,40 & 3,07 & 0,62 & 20 \\
\hline
\end{tabular}




\section{Travel Speed Fluctuation}

Congestion was used to evaluate the success of the transportation network and to identify existing problems in the research location. This illustrated the manner a system achieves predetermined goals and targets, including describing the experience of the users. In addition, some of these measures illustrate the duration of congestion experienced by the users, including delay and travel times, as well as average speed. Consequently, variations in demand and supply, which were dependent on location, departure time and occurrence of special event, tend to affect the reliability of the road network.

The examples travel speed fluctuation of road network plotted in the X-Y axis is shown in Figures 3 and 4 . The $\mathrm{X}$-axis depicts the travel time while the $\mathrm{Y}$ axis is the travel speed. In Figure 3, an extremely slow travel speed (less than $10 \mathrm{~km} / \mathrm{h}$ ) was detected on several segments of the Z.A. Pagar Alam Road, including the Tugu-MBK and reverse directions. Furthermore, in the Tugu-MBK direction as shown in Figure 3, where a remarkable slow speed was detected close to the Rajabasa Bus Station (with a traffic light), UNILA underpass to the Abdul Muis Street (due to the U-turn facility), and Untung Surapati Street which intersects each other at Pelita-1 Street (as a result of four U-turn facilities). In MBK-Tugu, the speed detected was less than $10 \mathrm{~km} / \mathrm{h}$ in the segments from MBK to Untung Surapati Street intersection and this is as a result of roadside activities such as street vendors, shops, schools, universities and two vehicular U-turn facilities.

Furthermore, Figure 4 shows the travel speed pattern on Teuku Umar Road. However, from MBK to Tanjung Karang, absolutely slow travel speeds and congestion in several segments such as the intersection between MBK and Urip Sumoharjo Street (due to a U-turn facility and minor road drivers from Urip Sumoharjo Street seeking to join the traffic), Advent Hospital (as a result of in or out vehicular activities and three U-turn facilities) and the intersection between Sam Ratulangi Street and Abdul Muluk Regional Hospital (RSUD Abdul Muluk). In the Tanjung Karang-MBK direction, an average travel speed of approximately less than $8 \mathrm{~km} /$ hour often occurred during peak hours from the Koga Market to Urip Sumoharjo Street. Several activities that disrupt vehicle speed such as roadside parking and three U-turn facilities were discovered.

Congestion and extremely slow travel speeds often occur on Radin Inten Road on the segments and intersection between Pemuda and Katamso Streets. This was caused by few drivers from Pemuda Street trying to either join or overtake the traffic. A fairly constant travel speed was observed on Ahmad Yani's
Road and along its segment. Furthermore, an extremely slow travel speed on R.A. Kartini Road often occurred on the segments of Katamso Street which intersects at Imam Bonjol Street. This was caused by (1) few drivers from Katamso Street trying to either join or overtake the traffic, (2) pedestrians seeking to cross the road, (3) roadside activities such as parking and street vendors, and (4) some drivers from Imam Bonjol Street. An efficient road network is gained through proper planning of land use. Therefore, the identification of the impact of land use on transportation system is necessary.

\section{The Characteristics of Travel Time Reliability}

Figure 5 highlights the distribution of average travel time profiles as a function of departure time on working days on the Z.A. Pagar Alam Road (from MBK to Tugu). Information regarding this effect is as follows, free-flow travel time, mean travel time, planning time and buffer time was 4.05, 7.49, 13.77 and 6.28 minutes respectively. Reliability measures also included the planning time index (3.40), buffer time index (0.84) and travel time index (1.80). Total travel time of 13.77 minutes was allocated for this trip by travellers intending to spend $95 \%$ of the travel time. The buffer time requirement was reduced when the $95^{\text {th }}$ percentile curve was drawn closer to the mean travel time curve. It simply means that the travel time reliability of the roads is much better.

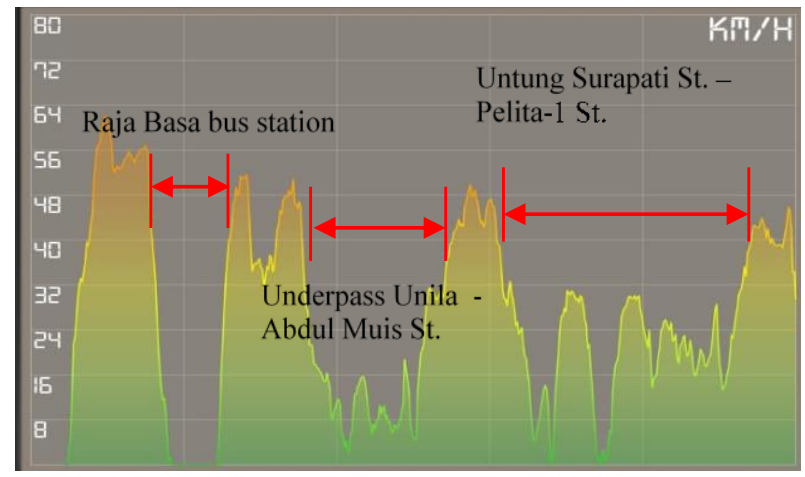

Figure 3. Travel Speed on Z.A. Pagar Alam Road, from Tugu Radin Inten to MBK at 16:32 PM

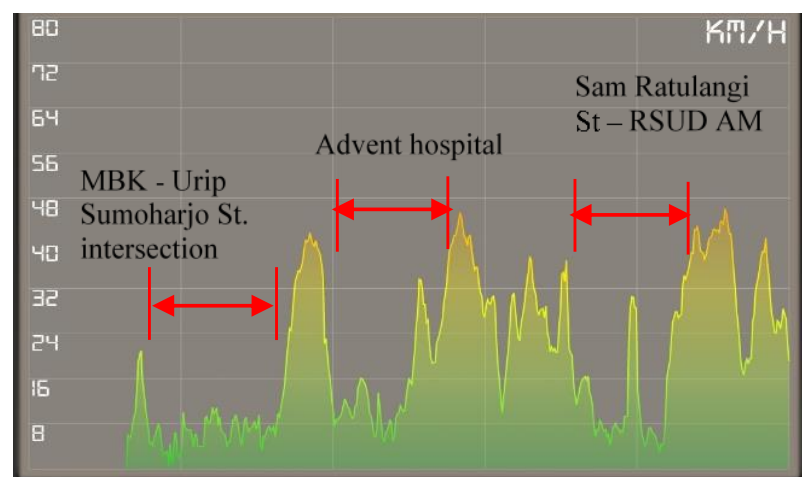

Figure 4. Travel Speed on Teuku Umar Road, from MBK to Tanjung Karang 


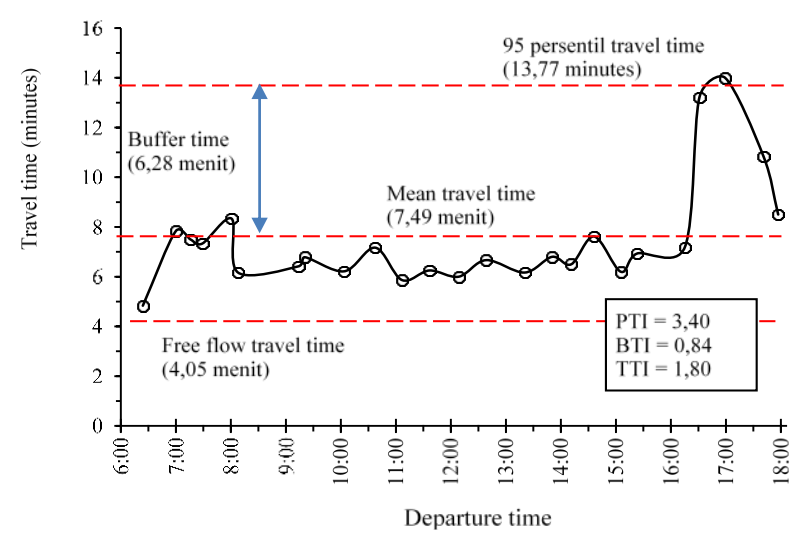

Figure 5. Z.A. Pagar Alam Road Travel Time Distribution

It is one of the indicators used to assess the management of the road network. Moreover, travel time reliability is an important measure of quality services. Subsequently, assuming a trip is unreliable, travelers are bound to encounter unexpected experiences as well as feel dissatisfied. On the contrary, the reverse tends to be the case when the conditions are estimated, and the travel time is reliable.

Table 3 shows the primary characteristics of travel time reliability for all road networks. Three performance measures were selected, namely planning time, buffer time and travel time indices. Planning time index illustrates the level of complexity involved in congestion. It also depicts the most severe level of a traffic jam at any certain time compared to free-flow traffic condition. The planning time index for Z.A. Pagar Alam Road is within the range of 3.0 and 3.5 as the highest level and analyzed as the busiest route in term of the FFTT. Furthermore, the buffer time index shows the extra time is needed by the travellers to ensure that the arrival time is within $95^{\text {th }}$ percentile travel time. The buffer time index for Z.A. Pagar Alam and Teuku Umar was significantly higher than the other three roads, which is almost more than twice the mean travel time. Consequently, the travel time index is a performance measure for congestion. The value of travel time is definitely similar to the travel time index.
Statistical analysis was carried out to determine the correlation between reliability (PTI) and congestion measures (TTI) for the five roads in this study, as shown in Figure 6. A straight line with a higher coefficient of determination $\mathrm{R}^{2}(0,768)$ was obtained from the graph. The relation between PTI and TTI derived from all sets of data led to the formulation of Eq. 4.

$\bar{t}=0.352\left(T_{\text {plan }}\right)+0.7129(F F T T)$

where $\bar{t}$ is average travel time (minutes), $\mathrm{T}_{\text {-plan }}$ is planning time (minutes), and FFTT is free-flow travel time (minutes).

Travel time reliability is one of the tools used to control the amount of congestion experienced by road users at a particular time. It is a measure of the travel time variability at different times. According to Table 2, the coefficient of variation on Z.A. Pagar Alam and Teuku Umar Roads is greater than 20 percent while the values of the other three roads are lesser. As stated earlier, the travel time reliability depends on its variability and estimated travel time. A trip that shows a slight variation in travel time has adequate reliability. Therefore, a road network that offers a high level of service tends to possess excellent reliability, which is also an additional measure by which external activities tend to affect travel time. Similarly, a trip that has a low-reliability value is greatly affected by various events.

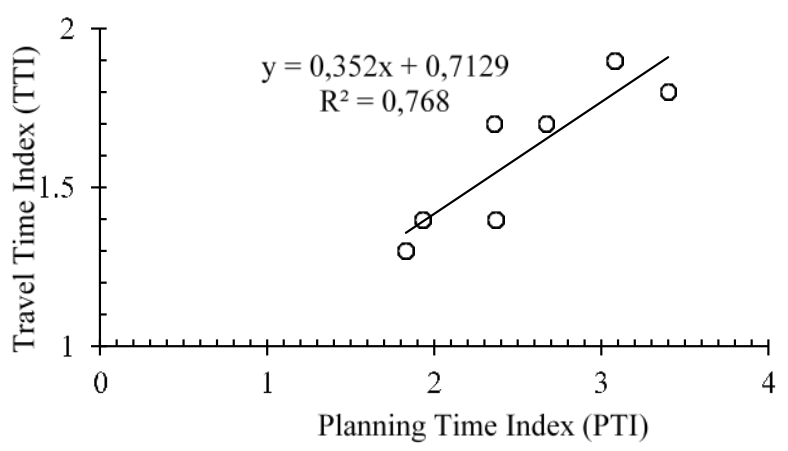

Figure 6. Relationship between Planning Time Index and the Travel Time Index. The graph shows average values as a function of departure time on workdays.

Table 3. The characteristics of Travel Time Reliability

\begin{tabular}{lccccc}
\hline \multicolumn{1}{c}{ Road name } & $\begin{array}{c}\text { Planning } \\
\text { Time (minutes) }\end{array}$ & $\begin{array}{c}\text { Planning Time } \\
\text { Index }\end{array}$ & $\begin{array}{c}\text { Buffer } \\
\text { Time (minutes) }\end{array}$ & $\begin{array}{c}\text { Buffer Time } \\
\text { Index }\end{array}$ & $\begin{array}{c}\text { Travel Time } \\
\text { Index }\end{array}$ \\
\hline $\begin{array}{l}\text { Z.A. Pagar Alam: } \\
\text { - from MBK to Tugu }\end{array}$ & 13,77 & 3,40 & 6,28 & 0,84 & 1.8 \\
- from Tugu to MBK & 12,02 & 3,08 & 4,58 & 0,62 & 1.9 \\
Teuku Umar & & & & & \\
- from MBK to T.Karang & 9,20 & 2,67 & 3,46 & 0,60 & 1.7 \\
- from T.Karang to MBK & 9,71 & 2,37 & 4,03 & 0,71 & 1.4 \\
Radin Inten & 4,83 & 1,93 & 1,30 & 0,37 & 1.4 \\
Ahmad Yani & 1,60 & 2,36 & 0,47 & 0,42 & 1.7 \\
R.A. Kartini & 4,39 & 1,83 & 1,32 & 0,43 & 1.3 \\
\hline
\end{tabular}


Table 4. Variation of Travel Time (minutes)

\begin{tabular}{lccccccccc}
\hline Road name & \multicolumn{3}{c}{ AM peak } & \multicolumn{3}{c}{ Midday } & \multicolumn{3}{c}{ PM peak } \\
\cline { 2 - 10 } & Mean & SD & CoV (\%) & Mean & SD & CoV (\%) & Mean & SD & CoV (\%) \\
\hline Z.A. Pagar Alam & & & & & & & & & \\
- from Tugu to MBK & 7,0 & 1,7 & 24 & 6,8 & 0,7 & 10 & 9,8 & 2,2 & 23 \\
- from MBK to Tugu & 7,2 & 1,4 & 19 & 6,7 & 0,8 & 12 & 10,7 & 2,9 & 27 \\
Teuku Umar & & & & & & & & & \\
- from MBK to T.Karang & 6,5 & 1,6 & 25 & 6,1 & 1,4 & 23 & 6,5 & 0,9 & 13 \\
- from T.Karang to MBK & 5,9 & 0,9 & 15 & 5,5 & 0,7 & 12 & 7,1 & 2,3 & 32 \\
Radin Inten & 3,2 & 0,2 & 7 & 3,8 & 0,6 & 16 & 3,1 & 0,5 & 16 \\
Ahmad Yani & 1,0 & 0,2 & 17 & 1,1 & 0,2 & 17 & 1,4 & 0,3 & 19 \\
R.A. Kartini & 2,6 & 0,2 & 6 & 2,8 & 0,3 & 12 & 4,2 & 0,2 & 5 \\
\hline
\end{tabular}

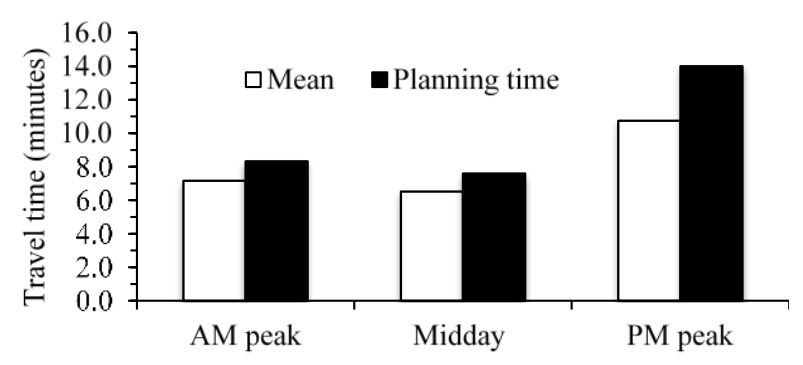

Figure 7. Departure Time Comparison for Z.A. Pagar Alam Road (from MBK to Tugu)

Based on Figures 3 and 4, it is evident that the variability that occurs on Z.A. Pagar Alam and Teuku Umar Roads was mostly caused by roadside activities such as markets, hospitals, schools and universities including vehicular U-turn over facilities.

It was discovered that most directional roads had different characteristics in the AM and PM peaks, including midday. Conversely, Figure 7 shows the respective value of the mean travel time and planning time. This shows that the travel time variability increases during the AM peak (06.00-08.00) followed by a decrease in the midday $(08.00-16.00)$ and an increase in the PM peak (16.00-18.00), respectively. This also proves that the planning time for the PM departure is longer than AM peak and midday, except for Radin Inten Road. Table 4 shows a comparison of mean travel time and planning time for each road. However, almost all the roads included in this analysis shows that the PM peak travel times were higher than those obtained in the AM. This was because the traffic volumes in the PM peak were generally higher or had experienced a greater degree than those in the AM.

\section{Conclusion}

Travel times were the results of a highly complex and dynamic interplay of various factors. These were categorized as influencing both travel time reliability and unreliability through the traffic demand (e.g. daily, weekly) activity patterns and supply (e.g. infrastructure capacity) respectively. Therefore, travel time reliability and its assessment were important to travelers and need to be highly prioritized in transport policy and performance management. Accordingly, it also needs to be encouraged in forecasting and appraisal studies.

Travel time reliability is an important indicator used to identify the performance and changes in a transportation system. Moreover, it is also a source of information for travelers. Based on the results of this research, temporal effects are the main factor that tends to affect travel time. It was discovered that there was an increase in travel time during the AM peak, followed by a decrease and an increase at midday and during the PM peak respectively. Similarly, some days of the week are more congested than others. All of these seasonal effects result in a certain bandwidth of travel demand during a typical peak hour of a typical off-peak hour. The second factor that tends to affect travel time is network effects that are the effect of traffic on adjacent, connecting or parallel links on the link of interest.

Based on these results, improving and maintaining a standard of travel time reliability needs to be asserted as a goal for Kota Bandar Lampung. The government has to be committed to developing an efficient and safe transportation system that supports the goals of regional land use. Further, they need to evaluate the existing transportation system in order to assess travel time reliability. This research also shows the variations of travel time reliability across roadway segments and the need for its prioritization. Conclusively, the government of Kota Bandar Lampung needs to prioritize the improvement of travel time reliability measures including bottleneck, $u$-turn facility and roadside friction.

\section{References}

1. Tu, H., Monitoring Travel Time Reliability on Freeways, PhD Thesis, Department of Transport and Planning, Delft University of Technology, Delft, 2008, pp. 1-192. 
2. Higatani, A., Kitazawa, T., Tanabe, J., Suga, Y., Sekhar, R., and Asakura, Y., Empirical Analysis of Travel Time Reliability Measures in Hanshin Expressway Network, Journal of Intelligent Transportation Systems, 13(1), 2009, pp. 28-38, https://doi.org/10.1080/15472450802644454

3. Chang, J.S., Assessing Travel Time Reliability in Transport Appraisal, Journal of Transport Geography, 18(3), 2010, pp. 419-425, http://dx.doi.org/ 10.1016/j.jtrangeo.2009.06.012

4. Lyman, K. and Bertini, R.L., Using Travel Time Reliability Measures to Improve Regional Transportation Planning and Operations, Transportation Research Record, 2046(1), 2008, pp. 1-10, https://doi.org/10.3141/2046-01

5. Florida Department of Transportation (FDOT), The Florida Reliability Method in Florida's Mobility Performance Measures Program, Florida Department of Transportation Tallahassee, Florida, 2000

6 Federal Highway Administration, Travel Time Reliability: Making It There on Time, All the Time, https://ops.fhwa.dot.gov/publications/treliability/TTR_report.htm2020, 2020

7. Bremmer, D., Cotton, K.C., Cotey, D., Prestrud, C.E., and Westby, G., Measuring Congestion: Learning from Operational Data, Transportation Research Record, 1895(1), 2004, pp. 188-196, https://doi.org/10.3141/1895-24

8. Mahmassani, H.S., Hou, T., and Saberi, M., Connecting Networkwide Travel Time Reliability and the Network Fundamental Diagram of Traffic Flow, Transportation Research Record, 2391(1), 2013, pp. 80-91, https://doi.org/10.3141/ 2391-08

9. Bhouri, N., Haj-Salem, H., and Kauppila, J., Isolated Versus Coordinated Ramp Metering: Field Evaluation Results of Travel Time Reliability and Traffic Impact, Transportation Research Part C: Emerging Technologies, 28, 2013, pp. 155-167, https://doi.org/10.1016/j.trc.2011.11.001

10. Bates, J., Dix, M., and May, A.D., Travel Time Variability and Its Effect on Time of Day Choice for the Journey to Work, in 15th PTRC Summer Anual Meeting-Planning and Transport Research and Computation, London, 1987, pp. 293-311

11. Noland, R.B. and Polak, J.W., Travel Time Variability: a Review of Theoretical and Empirical Issues, Transport Reviews, 22(1), 2002, pp. 3954, https://doi.org/10.1080/01441640010022456
12. Shao, H., Lam, W., Meng, Q., and Tam, M., A Demand Driven Travel Time Reliability-Based Traffic Assignment Problem, Transportation Research Record, 2006 pp. 220-230

13. Liu, H.X., Recker, W., and Chen, A., Uncovering the Contribution of Travel Time Reliability to Dynamic Route Choice using Real-Time Loop Data, Transportation Research Part A: Policy and Practice, 38(6), 2004, pp. 435-453, https://doi.org/ 10.1016/j.tra.2004.03.003

14. Dong, J. and Mahmassani, H.S., Flow Breakdown and Travel Time Reliability, Transportation Research Record, 2124(1), 2009, pp. 203-212, https://doi.org/10.3141/2124-20

15. Dong, J., Mahmassani, H.S., and Lu, C.C., How Reliable is this Route? Predictive Travel Time and Reliability for Anticipatory Traveler Information Systems, Transportation Research Record, 1980(1), 2006, pp. 117-125, https://doi. org/10. 1177/0361198106198000116

16. Hasan, M., Ganguly, B., Chowdhury, S.R., Rahman, G.A., Sami, S., and Sultana, J., Analyzing the Impact of Land Use and Roadside Informal Activity on Transportation System: A Case Study in Rajshahi City Corporation, Bangladesh, International Journal of Transportation Engineering and Traffic System, 4(2), 2018, pp. 18-31

17. Li, Z., Hensher, D.A., and Rose, J.M., Willingness to Pay for Travel Time Reliability in Passenger Transport: A Review and Some New Empirical Evidence, Transportation Research Part E: Logistics and Transportation Review, 46(3), 2010, pp. 384-403, https://doi.org/10.1016/j.tre.2009.12.005

18. Cambridge Systematics Inc. and Texas Transportation Institute, Traffic Congestion and Reliability: Trends and Advanced Strategies for Congestion Mitigation, Federal Highway Administration, United States, Sept. 2005

19. Ando, N. and Taniguchi, E., Travel Time Reliability in Vehicle Routing and Scheduling with Time Windows, Networks and Spatial Economics, 6, 2006, pp. 293-311, https://doi.org/10.1007/ s11067-006-9285-8

20. Taylor, M.A., Modelling Travel Time Reliability with the Burr Distribution, Procedia-Social and Behavioral Sciences, 54, 2012, pp. 75-83, https://doi.org/10.1016/j.sbspro.2012.09.727

21. Chen, C., Skabardonis, A., and Varaiya, P., Travel-Time Reliability as a Measure of Service, Transportation Research Record, 2003, 1855(1), 2003, pp. 74-79, https://doi.org/10.3141/1855-09 